\title{
SOME ASPECTS OF PREVENTION OF POSTOPERATIVE COMPLICATIONS IN PATIENTS AFTER HEPATICO-JEJUNOSTOMY
}

\section{ДЕЯКІ АСПЕКТИ ПРОФІЛАКТИКИ ПІСЛЯОПЕРАЦЙНИХ УСКЛАДНЕНЬ У ХВОРИХ ПІСЛЯ ГЕПАТЕЮНОСТОМІї}

Резюме. У роботі обговорюється одне з актуальних питань сучасної абдомінальної хірургії, а саме профілактики ускладнень після накладання гепатико-еюноанастомозів. Серед основних причин значного погіршення прогнозу перебігу післяопераційного періоду, можна назвати розвиток неспроможності гепатико-еюноанастомозу або поява його стриктури. Для профілактики даної категорії післяопераційних ускладнень, на даний момент, широко використовуються різноманітні методи декомпресії шляхом дренування зазначених анастомозів, однак всі ці методи, не мають належної ефективності внаслідок наявності різних недоліків. Тому дане питання залишається актуальним і $є$ стимулом, для подальшого пошуку нових, більш ефективних методик. Запропонований власний метод дренування гепатико-єюноанастомозу, який полягає у застосуванні розробленої дводіаметральної дренажної трубки, початковий діаметр якої 2-3 мм, а кінцевий - до 5-7 мм. Даний метод був застосований в експерименті на 11 кроликах. Широка частина трубки (5-7 мм) вводиться в ділянку анастомозу, також, слугуючи йому підтримуючим каркасом. Тонка частина (2-3 мм) виводиться нижче гепатико-єюноанастомозу на передню черевну стінку через просвіт тонкої кишки, виконуючи декомпресійну функцію. Для видалення даної дренажної трубки в післяопераційному періоді, тонка частина трубки підтягується максимально до вільного ходу й і відсікається, а їі широка частина, яка залишилась в просвіті кишечника, зміщується каловими масами назовні. Спосіб апробовано у 7-ми пацієнтів. У чотирьох було субопераційне пошкодження загального печінкового протоку типу I-II по Bismuth-Strasberg під час лапароскопічних втручань на жовчному міхурі. У двох хворих був синдром Miрiззі IV типу, у одному випадку була неспроможність швів попередньо накладеного холедохо-дуоденоанастомоза. У всіх пацієнтів виконана гепатіко-еюностомія по типу Roux. У післяопераційному періоді у жодного хворого не виникло неспроможності швів, явищ холангіту чи кишкових нориць. У віддалені терміни (до 1,5 року) не виявлено ознак рубцевої стриктури анастомозу.

Ключові слова: гепатико-еюноанастомоз, дренаж, профілактика ускладнень.

Surgery on the extrahepatic bile ducts remains one of the most complicated operations in abdominal surgery, in spite of a wide introduction of up-to-date minor invasive surgical methods [1,2]. One of the most complicated and disputable issues is prevention of various post-operative complications occurring after applying biliary-enteric anastomosis, and first of all, after making hepaticojejunostomy [3, 4]. In these cases development of failure of anastomosis or its stricture is one of the severe and frequent complications. Their occurrence deteriorates prognosis considerably and may cause lethal outcome [5]. These issues become especially important during surgery concerning iatrogenic injuries of proximal regions of the extrahepatic bile ducts [6].

One of the main methods to prevent these complications is anastomosis drainage [7]. For this purpose external drainages are delivered, "lost" or "obscure" tubes are left, combined drainage is applied [1]. The main methods are: Saupol's method [8], Smith's method [9] and their modifications. Although none of the existing methods produces a proper effect.

Development of complications after application of biliary-enteric anastomosis is caused by a number of factors: inconsiderable thickness of bile duct walls which does not correspond with the thickness of the intestinal wall being anastomosed; a small diameter of the bile ducts stipulating a small diameter of anastomosis; inflammatory changes of the bile duct walls or their scar transformation; increased pressure in the lumen of anastomosis resulting in deterioration of blood circulation in the tissues; a negative bile impact possessing fibrinolytic action on the processes of formation of the connective tissue, as fibrin is deposited 
along the contact line of organs being anastomosed [8].

The main purpose of anastomosis drainage is decompression and bile drain. It reduces pressure in the area of anastomosis improving microcirculation in the tissues of organs being sutured. Bile drain reduces the processes of fibrin destruction and activation of intestinal enzymes participating in it. Therefore, conditions for regeneration improve. In addition, a drainage tube makes a frame preventing narrowing anastomosis [3].

External drainages provide bile excretion and reduced pressure in the lumen of anastomosis. Although insertion of tubes with larger diameter making a reliable frame effect might result in complications after the drainage is removed. The danger of formation of external intestinal abscess occurs, which is connected with the size of the opening in the jejunum and anterior abdominal wall, through which a drainage tube is coming outside. At the same time the drainage efficacy in the lumen of anastomosis decreases at the expense of slow outflow of bile through the tube of a bigger diameter. Application of a small diameter tube for external anastomosis promotes quicker evacuation of the contents, but a frame effect is not achieved and it creates preconditions for development of stricture of anastomosis $[1,6]$.

The use of internal drainage by means of "lost" tubes produces the frame effect only. Bile drain and decompression of the area of anastomosis are not provided, and duration of the tube insertion is not possible to control. The lost tube may be encrusted with bile acid salts promoting its fixation in the area of anastomosis resulting in its obstruction and disturbed bile drain. The tube may migrate into the lumen of an adductor part of the bile ducts and cause their obstruction $[1,5]$.

Therefore, development of drainage methods of biliary-enteric anastomosis able to provide optimal conditions for prevention of both early and remote complications is rather topical.

The objective of the research: to study the effecttiveness of the developed drainage method hepaticojejunostomy.
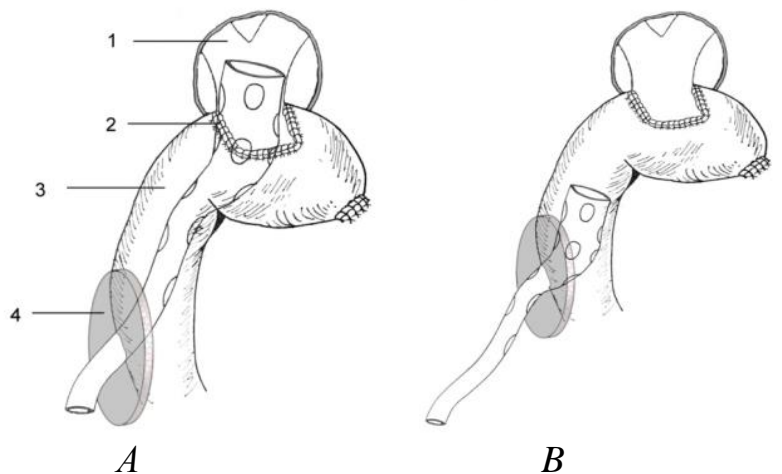

$B$

The object and method of research. Experimental studies were conducted on 11 inbred rabbits. Medial laparotomy was performed under general intravenous anaesthesia. Supraduodenal choledochal part was cut. The stump of an abductor portion was dressed. The stump of an adductor portion was anastomosed into the side of the initial part of the jejunum. In order to drain anastomosis according to the method developed a special two-diametral drainage tube was inserted into its lumen during surgery (Fig. A). The diameter of a working part of the drainage was 5-7 mm depending on individual requirements. The diameter of a free part was 2-3 $\mathrm{mm}$. a working part of the tube was placed in the lumen of anastomosis, and a free part was inserted through the intestinal lumen and drawn outside through the puncture of the anterior abdominal wall. On the $14^{\text {th }}$ day the tube was pulled by its free end till its working part sets against the intestinal wall (Fig. B), and after that it was cut (Fig. C). A working part of the tube left in the lumen migrated externally with dejection (Fig. D).

The method was tested in hospital on 7 patients. Four of them had sub-operating injury of the common bile duct by I-II Bismuth-Strasberg type [10, 11]. Two patients had IV type Mirizzi's syndrome [4] and one patient with failure of stitches of preliminary applied choledochoduodenoanastomosis. All the patients underwent hepaticojejunostomy by Roux type.

Results and discussion. A working part of the tube with dejection came off in 3 days in the experiment. There were no complications found after surgery. 3 months later the section of animals performed did not find any stenosis of the anastomosis made.

Drainage tubes were removed from the patients 12-15 days after cholangiography was performed in case there were no signs of cholangitis found. In every case a free passing of a contrast medium into the internal hepatic ducts and jejunum was found.

There was no suture failure or signs of cholangitis found in the patients. In one patient with obesity a part of the tube was left for a longer time in the abdominal

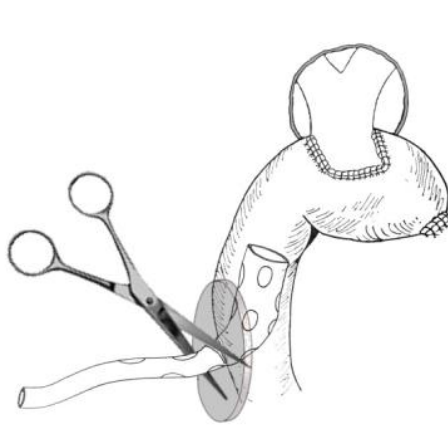

$C$

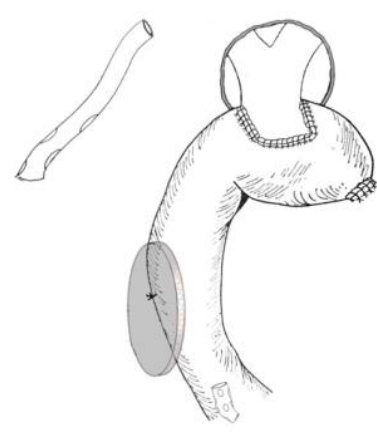

$D$

Figure. The scheme of the developed method of biliary-enteric anastomosis external drainage: 1 - right and left bile ducts; 2 -anastomosis; 3 -anastomosed loop of the jejunum; 4 -anterior abdominal wall 
wall, therefore it was pushed into the lumen of the jejunum by means of a thin probe. Intestinal abscess or any wound suppuration were not found in any of the cases. A part of the tube with dejection in 2 patients came off on the $4-5^{\text {th }}$ day after removal. The signs of anastomosis scar stricture were not found during a remote period (up to 1 year).

Naturally, a small number of observations does not enable to draw accurate conclusion. Nevertheless, the number of such patients is not large in general, and the first results obtained after application of the drainage are indicative of a possibility of its further wide use.

The method developed stipulates the combination of advantages from various methods and elimination of their defects at the expense of the two-diametral tube used. An enlarged diameter of its working part located in the lumen of anastomosis ensures a frame effect. A thin free part passing through the lumen of the jejunum drawn outside through the puncture of the anterior abdominal wall, according to Bernoulli's law, provides quicker bile drain at the expense of a small diameter. After the drainage is cut a part of the tube left in the lumen of the jejunum $10.0 \mathrm{~mm}$ long migrates freely with intestinal contents and comes out with dejection. A small diameter of a remaining defect in the intestinal wall and anterior abdominal wall, through which a free end of the drainage tube passes, promotes effective contraction of the intestinal smooth muscles creating conditions for quick healing and prevents formation of intestinal abscesses. So, proposed the method preventions origin of main complications $[6,7,12]$ due to biliojejunostomy.

Conclusion: the drainage method of hepatic-jejunal anastomosis developed has demonstrated clinical efficacy. It provides an effective bile drain and decompression of the anastomosis area, creates a reliable frame effect. Due to certain constructive peculiarities of the drainage tube occurrence of intestinal abscesses is prevented after removal of the drainage tube, and drainage presence in the anastomosis area is under control.

Outooks of the scientific inquiry. The obtained results of application of the proposed method of drainage of hepatocyanoanastomosis can be used in abdominal surgery to prevent their failure. It will also help to avoid strictures of these anastomosis in the remote postoperative period. This will give an opportunity to improve the treatment results of this category of patients.

\section{References}

1. Karvonen J, Gullichsen R, Laine S, Salminen P, Grönroos JM. Bile duct injuries during laparoscopic cholecystectomy: primary and long-term results from a single institution. Surg Endosc. 2007 Jul;21(7):1069-73. doi: $10.1007 /$ s00464-007-9316-7

2. Bismuth H, Franco D, Corlette MB, Hepp J. Long term results of Roux-en-Y hepaticojejunostomy. Surg Gynecol Obstet. 1978 Feb;146(2):161-7.

3. Buturovic S. Iatrogenic Injury to the Common Bile Duct. Med Arch. 2014 Aug;68(4):291-3. doi: 10.5455/medarh.2014.68.291-293

4. Csendes A, Díaz JC, Burdiles P, Maluenda F, Nava O. Mirizzi syndrome and cholecystobiliary fistula: $a$ unifying classification. Br J Surg. 1989 Nov;76(11):1139-43. doi: 10.1002/bjs.1800761110

5. Mercado MA, Sanchez N, Urencio M. Major hepatectomy for the treatment of complex bile duct injury. Ann Surg. 2009 Mar;249(3):542-3; author reply 543. doi: 10.1097/SLA.0b013e31819aa93d.

6. Lillemoe KD, Melton GB, Cameron JL, Pitt HA, Campbell KA, Talamini MA, et al. Postoperative bile duct strictures: management and outcome in the 1990s. Ann Surg. 2000 Sep;232(3):430-41. doi:10.1097/00000658-200009000-00015

7. Park DH. Endoscopic ultrasound-guided biliary drainage of hilar biliary obstruction. J Hepatobiliary Pancreat Sci. 2015 Sep;22(9):664-8. doi: 10.1002/jhbp.271.

8. Qin YS, Li QY, Yang FC, Zheng SS. Risk factors and incidence of acute pyogenic cholangitis. Hepatobiliary Pancreat Dis Int. 2012 Dec 15;11(6):650-4.

9. Saypol GM, Kurian G. A technique of repair of stricture of the bile duct. Surg Gynecol Obstet. 1969 May;128(5):1071-6.

10. Smith R. Transluminal T-tube drainage in pancreatobiliary surgery. A way out of difficulty. Lancet. 1965 Nov 20;2(7421):1063-6. doi: 10.1016/s0140-6736(65)90587-8

11. Strasberg SM, Hertl M, Soper NJ. An analysis of the problem of biliary injury during laparoscopic cholecystectomy. J Am Coll Surg. 1995 Jan;180(1):101-25.

12. Suzuki H, Shimura T, Mochhida Y, Wada S, Araki K, Kubo N, et al. To Stent or Not To Stent Hepaticojejunostomy-Analysis of Risk Factors for Postoperative Bile Leaks and Surgical Complication. Hepatogastroenterology. 2014 Jun;61(132):920-6. 


\section{НЕКОТОРЫЕ АСПЕКТЫ ПРОФИЛАКТИКИ ПОСТОПЕРАЦИОННЫХ ОСЛОЖНЕНИЙ У БОЛЬНЫХ ПОСЛЕ ГЕПАТИКОЭЕЮНОСТОМИИ}

Резюме. В работе обсуждается один из актуальных вопросов современной абдоминальной хирургии профилактики осложнений после наложения гепатикоеюноанастомоз. Среди основных причин значительного ухудшения прогноза течения послеоперационного периода, можно назвать развитие несостоятельности гепатико-еюноанастомозу или появление его стриктуры. Для профилактики данной категории послеоперационных осложнений, на данный момент, широко используются различные методы декомпрессии путем дренирования указанных анастомозов, однако все эти методы не имеют должной эффективности вследствие наличия различных недостатков. Поэтому данный вопрос остается актуальным и является стимулом для дальнейшего поиска новых, более эффективных методик. Предложенный метод дренирования гепатикоеюноанастомоза, который в основе которого лежит применение разработанной дводиаметральнои дренажной трубки, начальный диаметр которой 2-3 мм, а конечный - 5-7 мм. Данный метод был применен в эксперименте на 11 кроликах. Широкая часть трубки (5-7 мм) вводится в область анастомоза, служа ему поддерживающим каркасом. Тонкая часть (2-3 мм) выводится ниже гепатикоеюноанастомоза на переднюю брюшную стенку через просвет тонкой кишки, выполняя декомпрессионную функцию. Для удаления данной дренажной трубки в послеоперационном периоде, тонкая часть трубки подтягивается максимально до свободного хода и и отсекается, а ее широкая часть, которая осталась в просвете кишечника, смещается калом наружу. Способ апробирован на 7-ми пациентах. У четырех из них, было субоперационное повреждение общего печеночного протока I-II типа по Bismuth-Strasberg во время лапароскопических вмешательств на желчном пузыре. У двух больных был синдром Мириззи IV типа, в одном случае была несостоятельность швов предварительно наложенного холедохо-дуоденоанастомоза. У всех пациентов выполнена гепатикоеюностомии по типу Roux. В послеоперационном периоде ни у одного больного не возникло несостоятельности швов, явлений холангита или кишечных свищей. В отдаленные сроки (до 1,5 года) не выявлено признаков рубцовой стриктуры анастомоза.

Ключевые слова: гепатико-еюноанастомоз; дренаж; профилактика осложнений.

\section{SOME ASPECTS OF PREVENTION OF POSTOPERATIVE COMPLICATIONS IN PATIENTS AF- TER HEPATICOJEJUNOSTOMY}

Abstract. The study deals with the prevention of complications after applying hepaticojejunal anastomosis, which remains a topical issue of modern surgery. Development of anastomosis failure or its stricture deteriorates the prognosis considerably, and it can cause lethal outcome. The main method to prevent these complications is drainage of anastomosis, although the existing methods are not properly effective due to a number of defects. Therefore, the search for new more effective methods is rather reasonable. A newly developed method of drainage with the use of a two-diametral tube was introduced and performed in the experimental study on 9 rabbits. A wide part of the tube $(5-7 \mathrm{~mm})$ is inserted into the area of anastomosis, and a narrow part (2-3 mm) is taken out through the lumen of the jejunum. In order to be removed the tube is pulled to the abdominal wall and cut, and its wider part is coming out with dejection. The method was tested on 4 patients. Two of them had sub-operating injury of the common bile duct by I-II Bismuth - Strasberg type. One patient had IV type Mirizzi's syndrome characterized by failure of stitches of preliminary applied choledochoduodenoanastomosis. All the patients underwent hepaticojejunostomy by Roux type. None of the patients developed failure of stitches, signs of cholangitis, or intestinal abscess. The signs of anastomosis scar stricture were not found during a remote period (up to 1,5 year).

Key words: hepaticojejunal anastomosis, drainage, prevention of complications.

\section{Відомості про авторів:}

Білоокий Олександр В'ячеславович - кандидат медичних наук., асистент кафедри хірургії № 1 Вищого державного навчального закладу України «Буковинський державний медичний університет», м. Чернівці;

Гирла Ян Вікторович - кандидат медичних наук, асистент кафедри хірургії № 1 Вищого державного навчального закліду України «Буковинський державний медичний університет», м. Чернівці.

Information about authors:

Bilookyi Oleksandr V. - Candidate of Medical Sciences (Ph.D.), Assistant of the department of Surgery № 1, Higher State Educational Establishment of Ukraine «Bukovinian State Medical University», Chernivtsi;

Hyrla Yan V. - Candidate of Medical Sciences (Ph.D.), Assistant of the department of Surgery № 1, Higher State Educational Establishment of Ukraine «Bukovinian State Medical University», Chernivtsi. 